\title{
Covid-19: since the infection to protective measures and the consequences in the world economy
}

\author{
Covid-19: da infecção às medidas protetivas e as consequências na economia mundial
}

Covid-19: de la infección a las medidas de protección y las consecuencias en la economía mundial

Andréia Michelle Alves Cunha de Alcântara ${ }^{1 *}$, Ivan de Alcântara Barbosa Barros², Victor Mendonça Galvão ${ }^{1}$, Ivan Barbosa Barros ${ }^{3}$, Paulo Roberto Eleutério de Souza ${ }^{1}$.

\begin{abstract}
Objective: Accomplish a literature review that covers the main contents about the coronavirus disease (COVID-19): epidemiology, virology of the Severe Acute Respiratory Syndrome-coronavirus-2 (SARS-CoV2), pathogenesis, transmission, clinical aspects, diagnosis, potential treatment, prophylaxis and the negative impacts of the COVID-19 in the world economy. Literature review: Little is known about the infectivity mechanism of SARS-CoV-2, but as it is a new virus, it is believed that the entire human population is susceptible to infection and COVID-19. The disease was first reported in China and since then, there has been an exponential increase in the number of cases, causing the World Health Organization to declare it as a pandemic, the effects of which have been collapsing the health system and triggering a negative impact in the world economy. Final considerations: The capacity of the health system, the intervention of government authorities through the elaboration and execution of protective strategies and the cooperation of the population in the fulfillment of decrees are fundamental for the control of the pandemic, until sufficient knowledge about the virus exists and, consequently, a vaccine and specific treatment is developed.
\end{abstract}

Keywords: COVID-19, Coronavirus, SARS-CoV-2, Public health, Economy.

\section{RESUMO}

Objetivo: Realizar uma revisão de literatura que aborde os principais conteúdos sobre a COVID-19 (coronavirus disease): epidemiologia, virologia do SARS-CoV-2 (Síndrome Respiratória Aguda GraveCoronavirus-2), patogenia, transmissão, aspectos clínicos, diagnóstico, potencial tratamento, profilaxia e os impactos negativos da COVID-19 na economia mundial. Revisão bibliográfica: Pouco se sabe sobre o mecanismo de infectividade do SARS-CoV-2, mas, como se trata de um vírus novo, acredita-se que toda a população humana está suscetível à infecção e à COVID-19. A doença foi relatada inicialmente na China e, desde então, houve um aumento exponencial do número de casos, fazendo com que a Organização Mundial de Saúde a declarasse uma pandemia, cujos efeitos vêm colapsando o sistema de saúde e desencadeando um impacto negativo na economia mundial. Considerações finais: A capacidade do sistema de saúde, a intervenção das autoridades governamentais através da elaboração e execução de estratégias protetivas e a cooperação da população no cumprimento de decretos são fundamentais para o controle da pandemia, até que exista conhecimento suficiente sobre o vírus e, consequentemente, seja desenvolvida uma vacina e tratamento específico.

Palavras-chave: COVID-19, Coronavirus, SARS-CoV-2, Saúde pública, Economia.

1 Universidade Federal Rural de Pernambuco (UFRPE), Recife - PE. *E-mail: amacabama@hotmail.com

2 Instituto de Ensino e Pesquisa (INSPER), São Paulo - SP.

3 Universidade Federal de Pernambuco (UFPE), Recife - PE.

SUBMETIDO EM: 7/2020

ACEITO EM: 8/2020

PUBLICADO EM: 10/2020 
RESUMEN

Objetivo: llevar a cabo una revisión de la literatura que aborde los contenidos principales sobre COVID-19 (enfermedad por coronavirus): la epidemiología, la virología del SARS-CoV-2 (Síndrome respiratorio agudo severo-coronavirus-2), la patogénesis, la transmisión, los aspectos clínicos, lo diagnóstico, lo tratamiento potencial, profilaxis y los impactos negativos de COVID-19 en la economía mundial. Revisión bibliográfica: Poco se sabe sobre el mecanismo de infectividad del SARS-CoV-2, pero como se trata de un virus nuevo, se cree que toda la población humana es susceptible a la infección y al COVID-19. La enfermedad se informó por primera vez en China y desde entonces, ha habido un aumento exponencial en el número de casos, lo que ha provocado que la Organización Mundial de la Salud lo declare una pandemia, cuyos efectos han estado colapsando el sistema de salud y desencadenando un impacto negativo en la economía mundial. Consideraciones finales: La capacidad del sistema de salud, la intervención de las autoridades gubernamentales mediante de la elaboración y ejecución de estrategias de protección y la cooperación de la población en el cumplimiento de los decretos son fundamentales para el control de pandemia, hasta que haya suficiente conocimiento sobre el virus y en, consecuencia, una vacuna y el tratamiento adecuado se han desarrollado.

Palabras clave: COVID-19, Coronavirus, SARS-CoV-2, Salud pública, Economía.

\section{INTRODUCTION}

Coronavirus represents a serious threat to global health as previously evidenced for Severe Acute Respiratory Syndrome (SARS), caused by SARS-Coronavirus (SARS-CoV) and Middle East Respiratory Syndrome (MERS), caused by MERS-Coronavirus (MERS-CoV). Currently, the threat is evidenced for Coronavirus Disease-19 (COVID-19), caused by Severe Acute Respiratory Syndrome Coronavirus-2 (SARSCoV-2), the new member of the $\beta$-coronavirus genus, closely related to several bat coronaviruses and to SARS-CoV (ECDC, 2019).

Genetically, SARS-CoV-2 is an enveloped virus, single-stranded, positive-sense, genomic Ribonucleic Acid (RNA), composed of twenty-one (21) main proteins - sixteen (16) non-structural proteins (NSP) and five structural proteins (SP) -. The SPs are spike (S), membrane (M), envelop (E) and nucleocapsid (N) protein, besides the Hemagglutinin-Esterase (HE) protein (FEHR AR and STANLEY P, 2015). The virus connects its S-protein to the angiotensin-converting enzyme 2 (ACE2), human receptor, to entry on the host cell, establishing the beginning of the infection. Once the infection is installed, an unregulated immunological response can occur, triggering a series of events, such as the exaggerated release of pro-inflammatory chemicals and the increase in blood vessel extension and permeability (XIAOWEI L, et al., 2020).

The SARS-CoV-2 is highly contagious and the current suggestion about the transmission is that it has been occurring from person-to-person, mainly airway - through droplets of saliva derivative from sneeze, cough and exhalation in asymptomatic and symptomatic situations (ECDC, 2019).

Clinically, most people will experience no symptoms, others will experience mild to moderate nonspecific respiratory symptoms and a minimal part will develop serious symptoms due to COVID-19. Mild symptoms are flu-like, besides nonproductive cough and sore throat. Moderate symptoms present pneumonia and shortness of breath. Severe symptoms can trigger Acute Respiratory Distress Syndrome (ARDS) and Septic Syndrome (SS) leading to death (CHEN N, et al., 2020). Since the clinical symptoms are nonspecific and most COVID-19 patients are diagnosed with pneumonia, the confirmation of SARS-CoV-2 infection is preferably obtained from real-time reverse-transcription polymerase chain reaction (RT-PCR) test, that detects the RiboNucleic Acid (RNA) of the SARS-CoV-2 (NIH 2020).

However, even the patient presents the symptoms of the disease and there is confirmation from the laboratory diagnosis, there is no specific medication for the treatment of COVID-19. For mild to moderate respiratory symptoms the treatment is outpatient, while for severe cases is required intubation and mechanical ventilation, proceeding to transfer the patient to the Intensive Therapy Unit (UTI) (MUHAMMAD $A B, 2020)$. 
Furthermore, since there is no vaccine for SARS-CoV-2, the number of cases of COVID-19 has been exponentially increasing, which has been collapsing the health care system and triggering a negative impact in the world economy (SOUZA CDF, 2020).

Therefore, considering the severity of COVID-19, the objective of the literature review presented here is to address the main subjects of SARS-CoV-2 infection: epidemiology, virology, pathogenesis, transmission, clinical aspects, diagnosis, potential treatment, prophylaxis and the negative impacts of COVID-19 in the world economy.

\section{LITERATURE REVIEW}

\section{Historical and Epidemiological Aspects}

There is no accurate answer about how the SARS-CoV-2 reached humans. However, there are evidences that the coronavirus circulate among animals, natural hosts (JOEL OW, et al., 2013). As examples, SARS-CoV-like viruses identified in palm civets, raccoon dog and horseshoe bats, and the infection caused by MERS-CoV, which is related to direct or indirect contact with camels (LAU SK, et al., 2005; AZHAR El, et al., 2014).

The SARS-CoV-2 emerged in early December 2019, in Wuhan, Hubei province, China. On that occasion, some traders and goers to the Huanan wholesale seafood market were affected by severe pneumonia of unknown cause and on December 31, China notified the outbreak of inconclusive antecedent to World Health Organization (WHO) (WHO, 2020). As a result, on January 1, 2020, the Huanan sea food market was closed and on January 30, the viral outbreak was declared a Public Health Emergency of International Concern. Then, as of February 11, the name for the new coronavirus disease, COVID-19, was officially announced (WHO, 2020; HUANG C, et al., 2020).

Thenceforth, the number of infected people has been exponentially increasing, to the point that after three months, on March 2020, the disease was declared a pandemic, so far responsible for more than 930,000 deaths worldwide (WHO, 2020; WORLDOMETERS, 2020).

\section{Genome}

The coronavirus (CoVs) are genotypically and serologically divided into four subfamilies: alpha, beta, gamma and delta, respectively ( $\alpha, \beta, \gamma$, and $\delta$ ) CoVs. Human coronavirus infections are caused by $\alpha$-and $\beta$ CoVs. SARS-CoV-2, the virus responsible for COVID-19, belongs to Nidovirales order, Coronaviridae family, Coronavirinae subfamily and $\beta$-coronavirus genus (ECDC, 2019).

Genetically, the coronavirus is non-segmented, positive-sense ribonucleic acid (RNA) about of 30kb, containing a 5 'cap (a modified guanine - CAP structure) along with 3 ' poly-A (nucleotides with adenine polyA tail), that allow the virus to act as messenger RNA (mRNA) for translation of replicase polyproteins. The organization of the coronavirus genome is 5'-leader-UnTranslated Regions (UTR)-replicase-structural proteins-3'UTR-poly (A) tail with accessory genes interspersed within the structural genes at the $3^{\prime}$ end of the genome (MASTERS PS, 2006).

The SARS-CoV-2 contains twenty-one (21) main proteins: four Structural Proteins (SP) - shared among other coronaviruses; Hemagglutinin-Esterase (HE) protein, SP only shared among $\beta$-coronavirus; and sixteen Non-Structural proteins (NSP). The four structural proteins are spike (S), membrane (M), envelop (E) and nucleocapsid (N) protein (OU X, et al., 2020). S-protein, the distinctive structure on the surface of the coronavirus, is responsible for binding to the receptor on the host cell, angiotensin-converting enzyme 2 (ACE2), thus mediating the fusion between virus proteins and host cell membranes (XIAOWEI L, et al., 2020). M-protein contributes to membrane curvature, as well as binding to the nucleocapsid. E-protein enables the assembly and release of the virus playing an important role in pathogenesis. $\mathrm{N}$-protein binds the viral genome in a beads-on-a-string type conformation and makes association with the Non-Structural Protein (NSP) of the number three. This association probably helps to tie the viral genome to the replicasetranscriptase complex (RTC), and afterward packing the encapsulated genome into viral particles (WIT E, et al., 2016). 
The Hemagglutinin-Esterase (HE) protein acts as a hemagglutinin, binding sialic acids on surface glycoproteins and contains acetyl esterase activity. These activities are believed to contribute to the action of the S-protein and consequent viral spread (SNIJDER E, et al., 2003) (Figure 1).

Figure 1- SARS-CoV-2

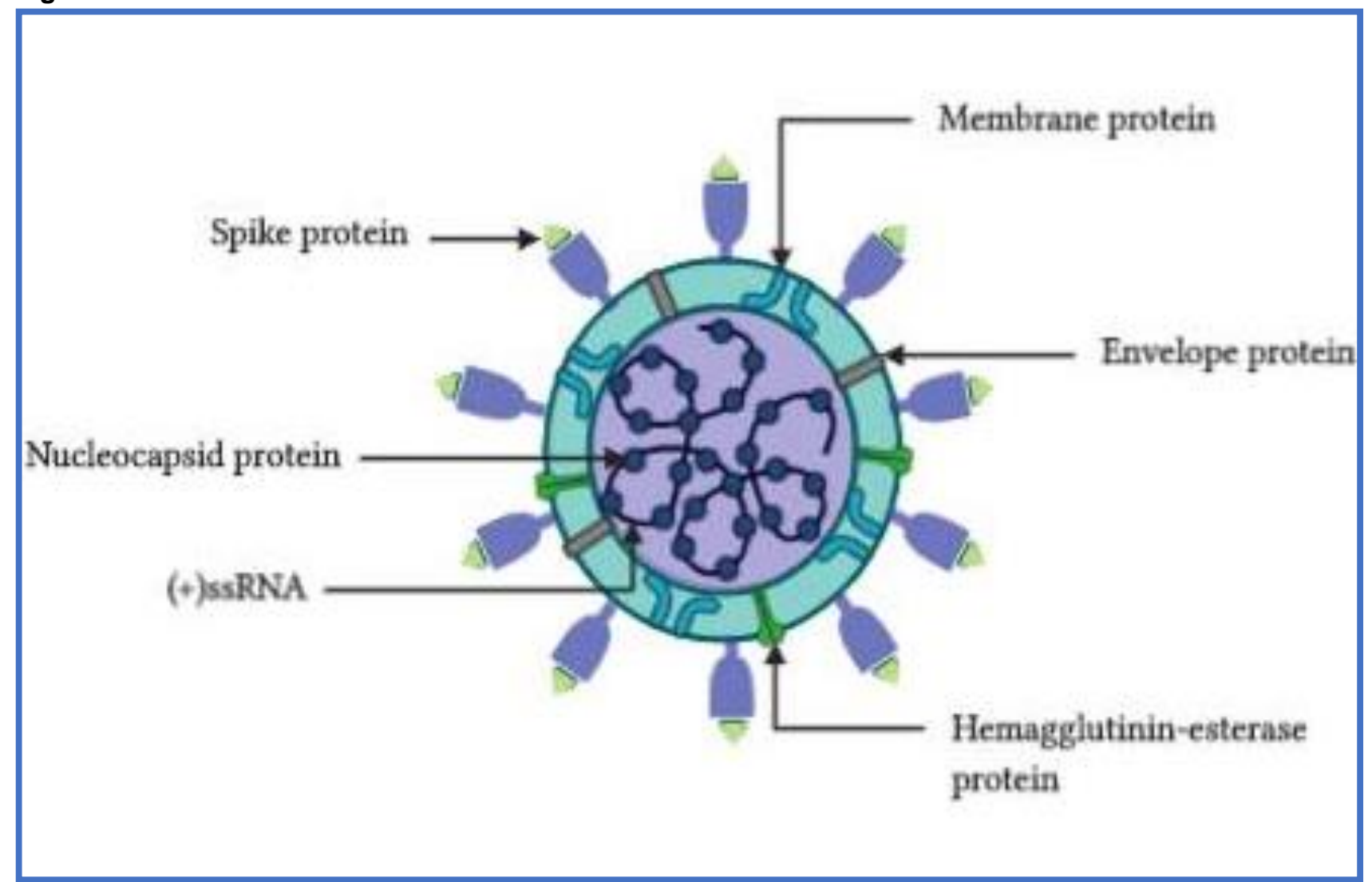

Legend: Spherical and enveloped virus, with helically symmetric nucleocapsids and a diameter of approximately 125 nanometer $(\mathrm{nm})$. Four structural proteins: Spike protein (S), Membrane protein (M), Envelope Protein (E), Nucleocapsid protein $(\mathrm{N})$ and Hemagglutinin-esterase protein (HE), only presents in $\beta$ coronavirus.

Source: Alcântara AMAC, et al., 2020; extracted data from National Center for Biotechnology Information (NCBI) BOOK, 2020 and the Image was created using bioRender.

The NonStructural proteins (NSPs) play a role to create a suitable environment for RiboNucleic Acid (RNA) synthesis, Replicase-Transcriptase Complex (RTC). Besides that, they have enzyme domains and functions that are responsible for RNA replication and transcription of the sub-genomic RNAs (WILDE AH, et al., 2018).

There are sixteen NSPs (1NSP-16NSP), interacting to accomplish the viral environment: Some of those proteins deregulate the host innate immune response, linking to prohibitin human proteins and inducing an exacerbated expression of cytokines. Other NSPs are responsible to form hexadecameric complex, also acting as primase, endoribonuclease, processivity clamp for RNA polymerase and helicase (WIT E, et al., 2016; OU X, et al., 2020).

Furthermore, the NSPs encode the RNA-dependent RNA polymerase domain (RdRp), contributing to add 5' cap (modified guanine - CAP structure) to viral RNAs, ExoN - (part of a gene that encodes a part of the final mature RNA) - and shielding viral RNA from some recognition (WILDE AH, et al., 2018; OU X, et al., 2020). 


\section{Virology and Pathogeny}

Similarly to other viruses, once the SARS-CoV-2 has contact with the individual, the virus needs the host's cellular machinery to complete its viral cycle and establish the infection (XIAOWEI L, et al., 2020). To enter the host cell, SARS-CoV-2 uses the densely glycosylated S-protein to connect to angiotensinconverting enzyme 2 (ACE2), human functional receptor. Once the S-protein of the virus is attached to ACE2 on the host healthy cell membrane, a vesicle is formed, and the virus travels inside the vesicle from the host cell membrane to the cell's nucleus, place where all genetic material are available (HUSSIN AR and SIDDAPPA NB, 2020). Then, the virus envelope and cell membrane vesicle combine, allowing the virus genetic material to leave the vesicle and enter the nucleus. At this moment, the virus hijacks the genetic materials inside the nucleus of the host cell to make hundreds to thousands of identical copies of the original virus (MIURA TA, et al., 2009).

Some of the viral genetic materials move out of the nucleus and attach to the human cytoplasmic organelles, ribosomes. These then, the ribosomes, use information from the viral genetic material to make other virus proteins such as the S-protein, M-protein, N-protein and C-protein, a packaging structure in the host cell. After that, the spikes are carried in vesicles, which merge with host cell's outer layer, the cell membrane. All the parts needed to create a new virus gather just beneath host cell's membrane (UNDERKNOWN, 2020). Finally, the virion-containing vesicles fuse with the plasma membrane of the cell to release the new virus. The new virus is ready to attach to a new cell, and the cycle is repeated (XIAOWEI $L$, et al., 2020; HUSSIN AR and SIDDAPPA NB, 2020) (Figure 2).

Figure 2- coronavirus cycle

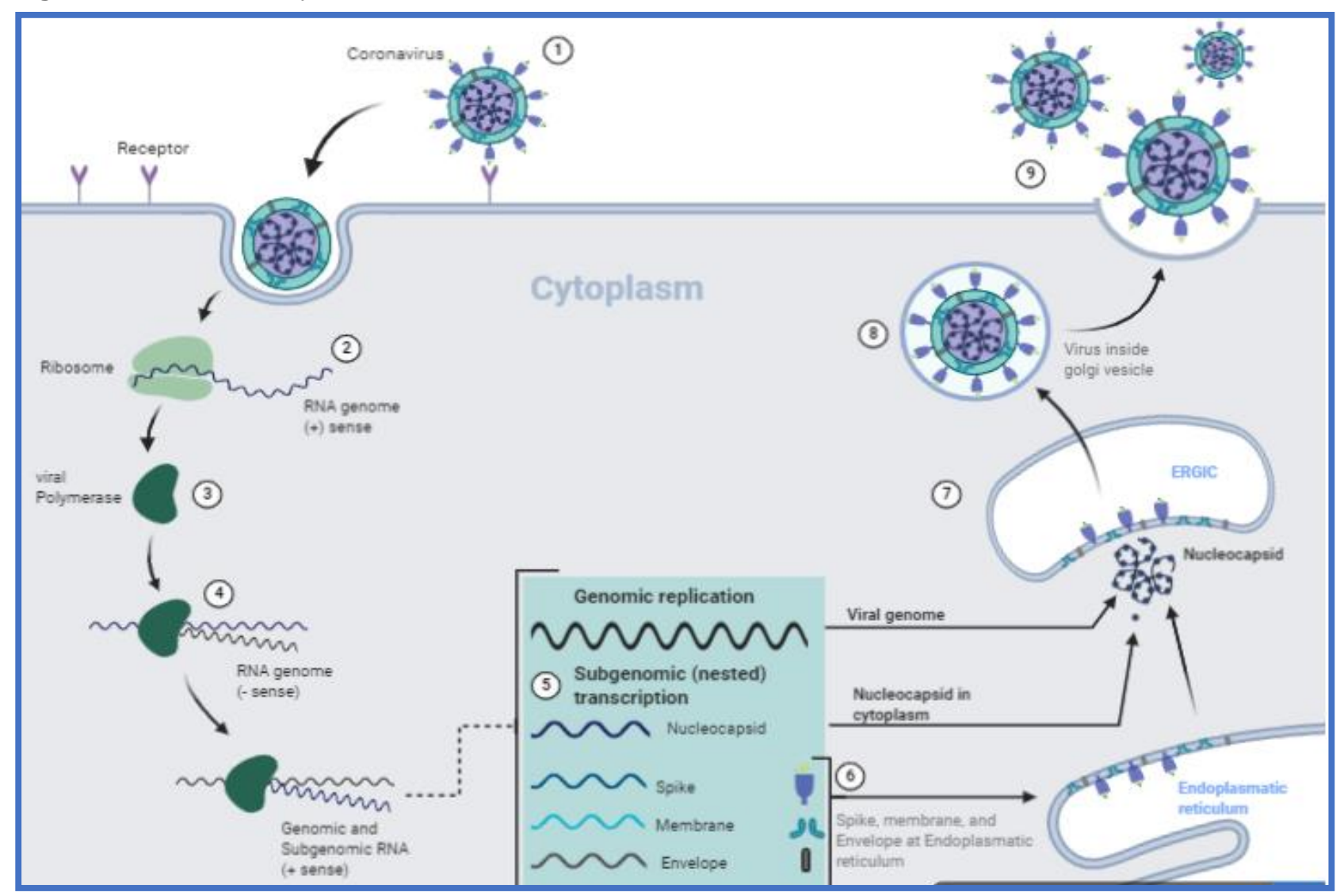

Legend:1) binding and viral entry via membrane fusion or endocytosis; 2) release of virus genome; translation of virus polymerase protein; 4) RNA replication; 5) subgenomic transcription; 6) translation of virus structures proteins; 7) S, E and M proteins combine with nucleocapsid; 8) formation of mature virion; 9) exocytosis.

Source: Alcântara AMAC, et al., 2020; extracted data from National Center for Biotechnology Information (NCBI) BOOK, 2020 and the Image was created using bioRender. 
The pathogenesis follows with an exacerbated host immune response due to viral infection. As the viral cell cycle occurs, the alveoli cells release unregulated pro-inflammatory chemicals such as cytokines, interleukins and tumor necrosis factor (TNF), triggering two important events (HUI L, et al., 2020): 1) blood vessel becomes permeable, which allow the blood and fluids from inside the vessels to pass through the pulmonary alveoli, threatening the blood vessel gas exchange between oxygen (O2) and carbon dioxide (CO2) (SINGER M, et al., 2016); 2) blood vessels extend supporting more and more blood and fluids. Consequently, the inflammatory chemical advances from vessels and alveoli towards all body, generating a systemic inflammation (HAMMING I, et al., 2004).

The association of worsening clinical progression with declining virus loads and the onset of an immunological response, plus the presence of elevated cytokines levels, suggest that severe lung damage is largely immunopathological in nature (HAMMING I, et al., 2004; HAIBO Z, et al., 2020).

\section{Transmission}

SARS-CoV-2 is extremely infectious, being able to live in the air and on surfaces between several hours and several days, respectively. Transmission can occur through simple contact with the virus over the mucous membranes, as well as the most expressive way, through airway derived droplets of saliva from human-to-human (ECDC, 2019).

Regarding transmission through simple contact, coronavirus is viable for up to 72 hours on plastics, 48 hours on stainless steel, 24 hours on cardboard, and 4 hours on copper. The infection may happen in viral survival period if the individual touches the contaminated surface and raises hands to face or mucous membranes (DOREMALEN NV, et al., 2020).

Transmission from human-to-human seems to be mainly airway through droplets of saliva derivative from sneeze, cough and even exhalation. There is an estimate that one infected person has the potential to infect between two and three more. In addition, studies demonstrated that some patients who had been recovered from COVID-19 can still result a positive reverse transcription polymerase chain reaction (RT-PCR) test (LAN L, et al., 2020).

In summary, asymptomatically infected persons, symptomatic patients or recovered from COVID-19 may pose a potential threat for the spread of the virus, hindering prevention and control (ECDC, 2019).

\section{Clinical Features}

The clinical spectrum of SARS-CoV-2 infection can be extremely different between the individuals, varying from asymptomatic to multiorgan dysfunction syndrome (MODS), known as Septic Syndrome (SS). Most people will experience no symptoms, while other will experience mild to moderate respiratory symptoms, and a minimal part will suffer severe symptoms leading to death. To simplify the understanding of the COVID-19 clinical features, the symptoms can be divided into mild illness, Severe Pneumonia, Acute Respiratory Distress Syndrome (ARDS) and Septic Syndrome (SS) (ECDC, 2019). Mild symptoms: usually are nonspecific such flu-like, including fever, unproducible cough, sore throat, nasal congestion, malaise, headache and muscle pain $(\mathrm{NIH}, 2020)$.

Severe pneumonia: besides the previous symptoms, fever can be moderate or even absent. However, in the occurrence of fever, it is associated with severe dyspnea, respiratory distress, tachypnea (elevated respiratory rate) and hypoxia (condition in which the body or a region of the body is deprived of adequate oxygen supply at the tissue level). In children can occur bluish cast to the skin and mucous membranes, known as cyanosis (ECDC, 2019).

Acute Respiratory Distress Syndrome (ARDS): the observed symptoms correspond to a serious newonset respiratory failure. These respiratory failures are distinguished based on the degree of hypoxia. The reference parameter is divided into mild, moderate, and severe ARDS, related to the partial pressure of oxygen (PaO2) / fraction of inspired oxygen (FiO2). Mild ARDS are referred when the patient presents 200 $\mathrm{mmHg}<\mathrm{PaO} 2 / \mathrm{FiO} 2 \leq 300 \mathrm{mmHg}$. Moderate ARDS are referred $100 \mathrm{mmHg}<\mathrm{PaO} 2 / \mathrm{FiO} 2 \leq 200 \mathrm{mmHg}$. Severe ARDS, references are PaO2/FiO2 $\leq 100$ mmHg (JEREMY B, et al., 2019; NIH, 2020). 
Septic Syndrome: presents the previous respiratory symptoms, plus a range of multiorgan infection involvement, including renal impairment with reduced urine output, tachycardia, altered mental status and in most cases leading to death (ECDC, 2019; $\mathrm{NIH}, 2020)$.

\section{Diagnostic}

Since the clinical symptoms are nonspecific and most COVID-19 infected patients are diagnosed with pneumonia, the confirmation of SARS-CoV-2 infection is obtained from laboratory tests. Currently, the Food and Drug Administration (FDA) recommends virological and serological tests, each for specific situations (NIH, 2020).

Authorized assays for virological tests include those that detect SARS-CoV-2 nucleic acid or antigen. The standard virological test for COVID-19 is the real-time reverse-transcription polymerase chain reaction (RT-PCR) - intended to detect the RiboNucleic Acid (RNA) of the SARS-CoV-2 via nucleic acid amplification test (NAAT) (CHUNQIN L, et al., 2020).

Serological test, otherwise known as antibody test, intends to identify patients with recent or prior SARSCoV-2 infection. The test detects the immunoglobulin $M(\operatorname{lgM})$ and the immunoglobulin $G(\lg G)$, blood proteins produced in response to and counteracting a specific antigen (ZHANG W, et al., 2020). Although the serological test is rapid and requires a minimal equipment, its accuracy may be limited for diagnosis of acute SARS-CoV-2 infection, due to the need for three weeks or longer after symptom onset for seroconversion or detection of IgM and IgG. Thus, the FDA recommends against the use of serologic testing as the sole basis for diagnosing acute SARS-CoV-2 infection ( $\mathrm{NIH}, 2020)$.

Currently, there are not enough tests for all suspected cases of COVID-19. Therefore, the Center for Disease Control and Prevention (CDC) has established a priority system for diagnostic testing based on the availability of the tests. According CDC test guidance, the population is divided into priority testing groups. Within the highest priority group are hospitalized patients with symptoms, health care facility workers, residents in long-term care facilities or other congregate living settings, including prisons and shelters with symptoms (CDC, 2020).

\section{Treatment}

There are no Food and Drug Administration (FDA) approved drugs for the treatment of COVID-19. Conversely, some medications such as Chloroquine Phosphate (CQ) and Hydroxychloroquine Sulfate (HCQ) are used through specific protocol, which is established by the health authorities of each country (BRASIL, 2020). In addition, therapies like Immune-Based Therapy (I-B T) and the antiviral drug named Remdesivir (RDV) are under evaluation about the efficiency and safety in humans (NIH, 2020).

Chloroquine and Hydroxychloroquine have already been used to treat malaria and autoimmune diseases, respectively. However, both $\mathrm{CQ}$ and $\mathrm{HCQ}$ are involved among controversial statements in the treatment of COVID-19 (MEHRA M, et al., 2020). For instance, some countries, including Brazil, guides these medications - mainly in the early stages of the disease (BRASIL, 2020) - while in contrast, other countries, including the United States of America (USA), disagree with the efficiency of $C Q$ and HCQ $(\mathrm{NIH}, 2020)$. About the QC and HCQ administration, the FDA announced on June 15, 2020, that these drugs are unlikely to be effective in treating COVID-19 for the authorized uses in the EUA. Additionally, considering ongoing serious cardiac adverse events and other serious side effects, the known and potential benefits of CQ and HCQ no longer outweigh the known and potential risks for the authorized use (MEHRA M, et al., 2020; NIH, 2020).

Moreover, several Immune-Based Therapies that are directed at modifying the course of COVID-19 are under investigation or are being used off-label. The treatment consists about using agents in two mechanisms: target the virus, for example convalescent plasma; or modulate the immune response, for example interleukin-1 [IL-1] or interleukin-6 [IL-6] inhibitors. However, according to the FDA, there are insufficient data to recommend either for or against the use of COVID-19 convalescent plasma or SARSCoV-2 immune globulins for the treatment of COVID-19 (NIH, 2020). 
Based on preliminary clinical trial data, the investigational antiviral agent Remdesivir is recommended for the treatment of COVID-19 in hospitalized patients with severe cases. Severe disease patients are the ones with peripheral capillary oxygen saturation $(\mathrm{SpO} 2) \leq 94 \%$ on ambient air or patients who require supplemental oxygen (SO), mechanical ventilation (MV), or Extracorporeal Membrane Oxygenation (ECMO). In addition, Remdesivir is available for children through an FDA Emergency Use Authorization or through a compassionate use program (MANLI W, et al., 2020; SHEARAN TP, et al., 2020)

Although there are no FDA approved drugs for COVID-19, a variety of drugs approved for other indications and multiple investigational agents are being studied for the treatment of COVID-19 around the world (NIH, 2020; SHEAHAN TP, et al., 2020).

\section{Prophylactic Measures versus Global Economy}

There is no vaccine to prevent infection with the SARS-CoV-2 virus. As the SARS-CoV-2 spreads, the COVID-19 causes a breakdown in the health system and a negative impact in the world economy (SOUZA CDF, 2020). In attempt to decelerate the viral spread, the CDC announced prophylactic measures based on general recommendations and governmental decrees (CDC, 2020).

General recommendations are relative to hygiene and etiquette habits, while the governmental decrees are relative to measures such as screening and/or blocking movement of individuals, cancelling mass gatherings, temporarily suspend school activities, religious services, cultural and sport events, closing of trade and non-essential services, and even lockdown the city (CDC, 2020; UN, 2020). However, these measures taken by most countries worldwide to control the COVID-19 pandemic, result in massive consequences for the local communities and for the global economy (SOUZA CDF, 2020). For instance, rapid fall in the values of financial assets, fall in imports and exports of products, retraction in industrial activity, rising inflation, reduced salaries, reduced taxes contribution, rising unemployment, and falling tourism and service provision (IBD, 2020).

Consequently, the population is becoming increasingly dependent and susceptible to the political actions of its local and national government authorities, especially in the ambit of financial social assistance and health care (AHAMED F, et al., 2020; PS, 2020). Government authorities, regardless of the current economic threat caused by COVID-19, remain responsible for predicting and supplying protective strategies, equipment, test, as well as treatment for general population and healthcare providers. Furthermore, to emphasize the responsibility of government authorities, it is important to note that the minimum misunderstanding or ignoring evidence in clinical practice and public health can expand the threat to global proportions (KOLIFARHOOD G, et al., 2020).

\section{FINAL CONSIDERATIONS}

Once SARS-CoV-2 is a new virus, it is believed that the entire human population is susceptible to COVID19. The certain in the moment is that the capacity of the health system, the cooperation of the population and, mainly the intervention of government authorities are fundamental to handle the pandemic, until enough knowledge about the virus exists and, consequently, a vaccine and appropriate treatment is developed.

\section{REFERENCES}

1. AHAMED F, et al. Why inequality could spread COVID-19. The Lancet. 2020; 5:(5) 240.

2. AZHAR El, et al. Evidence for Camel-to-Human Transmission of MERS Coronavirus. The New England journal of medicine. 2014; 370:2499-2505.

3. BRASIL. Ministério da Saúde. Agência-Saúde. CORONAVIRUS COVID-19: Orientações para uso da cloroquina. Brasília: DF, 2020.

4. CENTERS FOR DISEASE PREVENTION AND CONTROL. Evaluating and Testing Persons for Coronavirus Disease 2019 (COVID-19). Atlanta, Geórgia: CDC, 2020.

5. CHEN N, et al. Epidemiological and clinical characteristics of 99 cases of 2019 novel coronavirus pneumonia in Wuhan, China: a descriptive study. Lancet. 2020; 395:507-513.

6. CHUNQIN L, et al. Diagnosis of the Coronavirus disease (COVID-19): rRT PCRorCT. European Journal of Radiology. 2020; 126:(10) 89-91. 
7. DOREMALEN NV, et al. Aerosol and Surface Stability of SARS-CoV-2 as Compared with SARS-CoV-1). N Engl Journal Med. 2020; 382:1564-1567.

8. EUROPEAN CENTRE FOR DISEASE PREVENTION AND CONTROL. COVID-19 background-disease. Solna, Suécia: ECDC, 2019.

9. FEHR AR, STANLEY P. Coronaviruses: An Overview of Their Replication and Pathogenesis. Methods Mol Biol. 2015; 1282:1-23.

10. HAMMING I, et al. Tissue distribution of ACE2 protein, the functional receptor for SARS coronavirus. A first step in understanding SARS pathogenesis. 2004; 203(2):631-37.

11. HAIBO Z, et al. Angiotensin-converting enzyme 2 (ACE2) as a SARS-CoV-2 receptor: molecular mechanisms and potential therapeutic target. 2020; 46:586-590.

12. HUANG C, et al. Clinical features of patients infected with 2019 novel coronavirus in Wuhan, China. Lancet. 2020; 395(10223):497-506.

13. HUI L, et al. SARS-CoV-2 and viral sepsis: observations and hypotheses. Lancet. 2020; 395 (10235):1517-1520.

14. HUSSIN AR, SIDDAPPA NB. The epidemiology and pathogenesis of coronavirus disease (COVID-19) outbreak. J Autoimnum. 2020; 109:102433.

15. INSTITUTO BELISARIO DOMÍNGUEZ SENADO DE LA REPÚBLICA. Posibles efectos del Coronavirus en la economía mundial. Ciudad de México: IBD, 2020.

16. JEREMY B, et al. Evolving definition of acute respiratory distress syndrome. Journal of thoracic disease. 2019; 11(3): 5390-5393.

17. JOEL OW, et al. A Case for the Ancient Origin of Coronaviruses. J Virol. 2013; 87(12): 7039-45.

18. KOLIFARHOOD G, et al. Epidemiological and Clinical Aspects of COVID-19; a Narrative Review. Arch Acad Emerg Med. 2020; 8(1):41.

19. LAN L, et al. Positive RT-PCR Test Results in Patients Recovered From COVID-19. JAMA. 2020; 323(15):15021503.

20. LAU SK, et al. Severe acute respiratory syndrome coronavirus-like virus in Chinese horseshoe bats. Proc. Natl. Acad. Sci. USA. 2005; 102(39):14040-45.

21. MANLI W, et al. Remdesivir and chloroquine effectively inhibit the recently emerged novel coronavirus (2019-nCoV) in vitro. Cell Res. 2020; 30(3): 269-271.

22. MASTERS PS. The molecular biology of coronaviruses. Adv. Virus Res. 2006; 66:193-292.

23. MEHRA MD, et al. Hydroxychloroquine or chloroquine with or without a macrolide for treatment of COVID-19: a multinational registry analysis. TheLancet. 2020; 6736(20)31180-6.

24. MIURA TA, HOLMES KV. Host-pathogen interactions during coronavirus infection of primary alveolar epithelial cells. J Leukoc Biol. 2009; 86(5): 1145-51.

25. MUHAMMAD AB. The COVID-19 Intubation and Ventilation Pathway (CiVP): a Commentary. Arch Acad Emerg Med. 2020; 8(1):37.

26. NATIONAL INSTITUTES OF HEALTH. COVID-19 Treatment Guidelines. Bethesda, Maryland: NIH, 2020.

27. OU X, et al. Characterization of spike glycoprotein of SARS-CoV-2 on virus entry and its immune cross-reactivity with SARS-CoV. Nature Communications. 2020; 11:1620.

28. PROJECT SYNDICATE ORG. 2020. In: Coronavirus and the Global Economy. New York: The World's opinion page. Avaliable from: https://www.project-syndicate.org/commentary/coronavirus-global-economy-lack-of-americanleadership-by-simon-johnson-2020-02?barrier=accesspaylog. Access in: 03 March. 2020

29. SHEARAN TP, et al. Comparative therapeutic efficacy of remdesivir and combination lopinavir, ritonavir and interferon beta against MERS-CoV. Nat commun. 2020; 11(1): 222.

30. SINGER M, et al. The third international consensus definitions for sepsis and septic shock (Sepsis-3). JAMA. 2016; 315: 801-810.

31. SNIJDER EJ, et al. Unique and conserved features of genome and proteome of SARS-coronavirus, an early split-off from the coronavirus group 2 lineage. J. Mol. Biol. 2003; 331(5): 991-1004.

32. SOUZA CDF. War economy and the COVID-19 pandemic: Inequalities in stimulus packages as an additional challenge for health systems. Rev. Soc. Bras. Med. Trop. 2020; 53.

33. UNDERKNOWN. 2020. In: What happens in your body if you caught the coronavirus. Toronto: what if. available in: https://whatifshow.com/coronavirus-animation-short-film/. Access in: 03 March. 2020

34. UNITED NATION. Toxic lockdown culture' of repressive coronavirus measures hits most vulnerable. Nova York: UN, 2020.

35. WORLD HEALTH ORGANIZATION. Naming the coronavirus disease (COVID-19) and the virus that causes it. Genebra, Suíça: WHO, 2020.

36. WILDE AH, et al. Host Factors in Coronavirus Replication. In Roles of Host Gene and Non-Coding RNA Expression in Virus Infection. Springer International Publishing. 2018; 419:1-42.

37. WIT E, et al. SARS and MERS: recent insights into emerging coronaviruses. Nat. Rev. Microbiol. 2016; 14(8): 52334.

38. WORLDOMETERS. Real time world statistics. COVID-19 CORONAVIRUS PANDEMIC. Dover, Delaware: 2020.

39. XIAOWEI L, et al. Molecular immune pathogenesis and diagnosis of COVID-19. Journal of Pharmaceutical Analysis. 2020; 10(2):102-108.

40. ZHANG W, et al. Molecular and serological investigation of 2019-nCoV infected patients: implications of multiple shedding routes. Emerg. Microbes Infect. 2020; 9(1):386-9. 